\title{
Class Struggles in China Today: Towards a Third Chinese Revolution?
}

\section{Élisabeth Allès}

Translator. N. Jayaram

\section{OpenEdition \\ Journals}

\section{Electronic version}

URL: http://journals.openedition.org/chinaperspectives/5773

DOI: 10.4000/chinaperspectives.5773

ISSN: 1996-4617

\section{Publisher}

Centre d'étude français sur la Chine contemporaine

\section{Printed version}

Date of publication: 30 March 2012

Number of pages: 3-4

ISSN: 2070-3449

\section{Electronic reference}

Élisabeth Allès, «Class Struggles in China Today: Towards a Third Chinese Revolution? », China Perspectives [Online], 2012/1 | 2012, Online since 30 March 2012, connection on 28 October 2019

URL : http://journals.openedition.org/chinaperspectives/5773 ; DOI : 10.4000/chinaperspectives. 5773

(c) All rights reserved 


\title{
Class Struggles in China Today:
}

\section{Towards a Third Chinese Revolution?}

\author{
ELISABETH ALLĖS
}

The passing of Elisabeth Allès, on 1 January 2012, came as a shock to many people, well beyond academia. Despite her grave illness, she had decided to attend a public workshop organized at the French National Library by the EHESS on 7 December 2011, devoted to " Revolutions today ". As a specialist of Islam, she had closely followed the recent changes in the Muslim world. An anthropologist attuned to the field, she always distinguished between the rigour of academic work and the choices of political commitment, but she was also able, when the opportunity arose, to associate the two, with the soft-spoken firmness that made up her character. The following essay represents her last public appearance and is published here as a tribute to her academic contribution and intellectual courage. (Joël Thoraval)

F or this day-long session on revolutions, I was asked to speak about China. This might seem a surprising topic, given the apparent strength of the Chinese Communist Party and its hold on society. I will focus on the main lines, changes, and contradictions in Chinese society that could lead to a third revolution, following the Revolution of 1911 and the Communist seizure of power in 1949.

\section{China's transformations}

Social upheavals are often in the news. It is worth noting that over the past 30 years, China has been in the throes of a major social transformation, similar to the one Marx described in nineteenth century England; (1) that is to say, the transformation from a rural peasant (80 percent) society into an urban worker (50 to 60 percent) society.

Apart from China's coastal provinces, where major enterprises are concentrated, townships in the interior regions have likewise been turning into cities since 2000. Migrant workers from all over China have fuelled this rapid development. This process, starting with Deng Xiaoping's re-launch of reforms in 1992, three years after the Tiananmen massacre, may be called "wild capitalism."

China's particularity lies in the fact that while this new capitalism does feature entrepreneurs, it is mostly directed by political leaders, party cadres, and their children. Moreover, it should be borne in mind that all land belongs to the state in China, and that the banking system relies on the state. For instance, banks can only lend at very low levels in conjunction with state institutions.

So Party leaders at all levels have turned into representatives of the bourgeoisie in the name of development, and the gulf between cadres and the general population has grown much wider.

Money-worship, irresponsibility, and corruption have spread to all strata of society. Scandals have implicated local Party leaders in numerous cases, such as the illegal sale of blood in Henan and the use of slave labour in Shaanxi brick kilns with protection from local authorities. A more gruesome example was that of a restaurateur who put rat poison in the food that a rival was supplying to schools and work spots.

China has come to be known as the workshop of the world. Many foreign companies, mostly from Taiwan, Japan, South Korea, and Hong Kong, are based in southern China: everyone has heard of the major Taiwanese firm Foxconn, with its military-style management. It supplies Dell, Apple, and Nokia (iPhones, iPads, etc.). The Shenzhen-based firm has 300,000 young workers (aged 18 to 24) from all over China. They work six days a week, 11 to 13 hours a day, earn about 120 euros a month, and live in dormitories.

\section{Struggle for wages}

The first protests against living and working conditions took the form of a series of suicides at Foxconn, forcing the firm to raise salaries in the face of public pressure.

As Marx pointed out, where there is exploitation, the struggle for wages unites a divided working class. Strikes in support of wage increases have proliferated, especially over the past two years in foreign companies such as Honda and Toyota based in the coastal areas, especially in Guangdong.

Thousands of workers have become active. Of course, the authorities have taken a kinder view of strikes in foreign companies, especially Japanese ones, than in Chinese firms. The official media take brief note of such strikes and gloss over those in Chinese companies. Most strikes have resulted in salary increases of 20 to 30 percent.

As official unions merely serve the purpose of controlling or blocking strike actions, workers have been organising on their own and using modern means of communication such as text messages, the Internet, and social networking. More recently there has been an upsurge in worker unrest, especially in view of factory relocations to China's hinterland, where wages are much lower.

It is an explosive situation, certainly in the coastal regions.

\section{The authorities' failures}

For more than a decade, the government has been launching a vast decentralisation movement in education, health, policing, and other sectors.

1. Karl Marx, The Poverty of Philosophy: Answer to the Philosophy of Poverty by M. Proudhon (first published 1847, Paris and Brussels). 
Although sometimes useful, decentralisation has ended up creating much inequality among provinces, cities, and districts, while boosting local autonomy. What is happening with local police forces now is characteristic of the criminal drift taking place, the central authorities being at best impotent or at worst complicit. These local police forces have more and more power, to the extent of setting up "black jails" in Beijing in order to block petitioners from taking their complaints to officials in the capital. There is also increasing recourse to the use of physical force to expel people from their homes and lands or during strikes. Violence breaks out and spreads rapidly. A recent example that springs to mind is a traffic accident caused by a cadre with a fancy car, which subsequently led to a riot.

The Chinese authorities posit their legitimacy on the idea of stability. Safeguarding growth is indispensable for this, with the result that many major projects are funded. However, this legitimacy faces threats from unforeseen issues such as deteriorating public health, environment, and food safety.

Everyone has heard of the melamine-laced milk powder scandal, which led wealthier mainlanders to buy supplies for their babies from Hong Kong and Macao. People are increasingly wary of foodstuffs following cases of "gutter oil," fake eggs, and other such frauds. A recent article in a Beijing daily denounced the practices of local administrations in Zhejiang, which diverted state subsidies to fund agro enterprises, which then sold their products to the governments at preferential rates.

\section{The gulf between Party cadres and the people}

Mao said: "Where there is oppression, there is resistance."

Apart from workers' strikes, there have also been revolts by farmers and urban residents against expropriation of their land or homes by local authorities for building factories or other projects. Rural revolts to protect a site or opposing pollution by a factory have routinely drawn thousands of people confronting police forces.

Different sectors of society have then joined to support such revolts, foremost among them lawyers and legal scholars. They have often succeeded in court, but decisions are not carried out. Lawyers have worked with Chinese laws to show the illegality and injustice of procedures.

Their courage is praiseworthy: most of them have had to pay a high price in the form of arrest, disappearance, beatings, and revocation of their lawyers' licences. It is worth mentioning the case of the blind civil rights activist Chen Guangcheng, now under house arrest after four years in jail for having denounced forced abortions in Shandong. Local police regularly harass him and his wife and vandalise his home. Last year, when several activists sought to visit him in his village for his $40^{\text {th }}$ birthday, many were arrested in Beijing and others on the way. Many people responded by posting Internet pictures of themselves with dark glasses in Chen's style.

Lawyers attract such severe reactions because the authorities perceive their potential to unite intellectuals with other strata of society. The intellectuals for their part came up with Charter 08, demanding democratic reforms. One of the authors, the Nobel Peace Prize winner Liu Xiaobo, received 11 years in jail for his pains.

While all these factors create conditions for a third revolution, others serve to delay it. So long as the state can ensure economic growth, it retains the support of a large section of the middle class. Furthermore, to the extent that the leadership remains united and overcomes divergent interests, it will no doubt be able to control tensions in the country.

However, revolutions are not announced in advance. It is always unforeseen incidents that provoke them; or as Mao Zedong said: "A single spark can start a prairie fire."

\section{Translated by N. Jayaram}

